\title{
Techniques in longitudinal studies of the skeletal development of the rat
}

\author{
By ROY M. ACHESON (Rockefeller Foundation Travelling Fellow, i 955-6; \\ Radcliffe Travelling Fellow, University College, Oxford, 1955-7) \\ Moyne Institute of Preventive Medicine, University of Dublin, Ireland \\ AND M. NEIL MACINTYRE AND ELEANOR OLDHAM \\ Department of Anatomy, Western Reserve University Medical School, \\ Cleveland, Ohio
}

(Received 20 October 1958-Revised 23 March 1959)

We have recently completed investigations into the effects of acute illness and of starvation on the skeletal development of albino rats of the Sprague-Dawley strain (Acheson \& Macintyre, I958a, $b$; Acheson, 1959). In planning this work we found it necessary to devise our own methods and techniques for frequent measurement and radiography of rats. The techniques proved to be satisfactory and we therefore submit a description of them together with some results obtained by their use.

METHODS

\section{Management of animals}

The young rats were weaned on the 20 th day, the sexes were separated, and the animals were kept in groups of not more than three per cage in a room whose temperature was thermostatically controlled at $69^{\circ} \mathrm{F} \pm \mathrm{I}^{\circ}$. The foodstuff, which was given ad lib. throughout the experiment, was 'Friskies' (Carnation Milk Company, 4045 Wilshire Boulevard, Los Angeles, California), a product intended primarily for dogs, but frequently used for small laboratory animals by research workers in the United States. It contains meat meal, bone meal, processed wheat, processed maize, hulled barley, ground oats, dried skim milk, wheat bran, wheat-germ meal, fish meal, fish oil, olive oil, soya-bean oil, soya-bean meal, dried beet-pulp, molasses, charcoal, iron oxide, iodized salt and aerated yeast.

\section{Length measurement of the conscious rat}

Western Reserve measuring board. The instrument used for measuring the experimental animals is shown in P1. $1 a$. It is made of transparent plastic material and consists of a measuring board and separate rider. The base of the measuring board is $45 \mathrm{~cm}$ long and is in two layers, between which is fastened a sheet of graph paper, ruled in $\mathrm{mm}$ and $\mathrm{cm}$. An end-piece with three holes (9, 12, and $19 \mathrm{~mm}$ in diameter) is permanently attached at right angles to the base. The bottom limit of each hole is flush with the upper surface of the base, and the graph paper is so placed that its 
zero line is exactly under the inner face of the end-piece. Every $5 \mathrm{~cm}$ along the paper the lines are accentuated, by overmarking with ink, to facilitate reading, and matching marks are scratched on the upper surface of the plastic covering the graph paper to eliminate errors of reading due to parallax.

Total-length measurement. The conscious rat is grasped by the scruff of its neck with the left hand and by the root of the tail with the right hand (Pl. I $b$ ). The animal is placed belly down on the measuring board, with its legs straddled and the tip of its nose just touching the end-piece of the board. It is important at this stage for the operator to impose a gentle pull between his two hands and at the same time to exert a slight pressure with the thenar eminence of his left hand on the animal's spine (P1. 2a). In this way the animal is prevented from humping its back and so causing an erroneous measurement. Finally, while the established position of the animal's tail root is maintained by pressing the right hand on the base, the hold on its neck is released. The operator's free left hand now extends the animal's tail along the measuring board, so that the scale can be read at its tip (Pl. $2 b$ ).

Tail-length measurement. The animal is held in the palm of the operator's hand and the tail is passed from the outside of the end-piece through the smallest hole that will easily accommodate it. With the animal's tail lying along the measuring board, the reading is taken at the tail tip $(\mathrm{Pl} .3 a)$. When absolute measurements of tail length are required, it is necessary to add the thickness of the end-piece to all readings $(0.6 \mathrm{~cm})$. However, when increments or the individual differences between measurements of experimental and control animals are being studied, this constant correction can be ignored.

\section{Weight measurement}

Each time an animal was measured its weight was determined on a spring balance and recorded.

\section{Radiography}

Skeletal maturation

In order that the maximum number of ossification centres should be recorded on a single film, it was necessary to standardize the position of the rat during radiography. It is essential that the animal be anaesthetized during this procedure; ether is a suitable agent for the purpose. The unconscious rat is fastened prone, with adhesive Cellophane tape, to a cassette containing X-ray film (Pl. $3 b$ ); one fore-limb is pronated and abducted from the body, and the other is supinated and adducted to the body. One hind-limb is fully extended, the other is flexed with the paw externally rotated. A radiogram taken with the animal in such a position is shown in Pl. 4 .

Contrary to the experience of other authors (Ingalls, I94I; Simpson, Asling \& Evans, 1950) we have found the use of fine-grain X-ray film unnecessary and have obtained satisfactory results with standard Kodak 'no-screen' film. The optimum exposure was $2 \cdot 2 \mathrm{sec}$ at $20 \mathrm{~mA}$ and a peak of $30 \mathrm{kV}$.

\section{Assessment}

Apart from the tables of Ray, Simpson, Li, Asling \& Evans (1950), we know of no comprehensive standards for the assessment of skeletal maturation in the rat. These 
tables are based on the skeletal-age technique and are open to the same criticisms that have been directed at this technique when it is applied to man (Acheson, 1954, I956, 1957). Therefore we have applied the principles of the Oxford method (Acheson, 1954, 1956, 1957) for assessing skeletal maturation to our studies of the rat. It is based on the fact that skeletal maturation is an irreversible process and that certain shape changes in the epiphyses of any long bone, or in the round bones, are visible radiographically and succeed each other in a fixed order. Such shape changes are known as maturity indicators. Consequently if a bone's more obvious indicators are

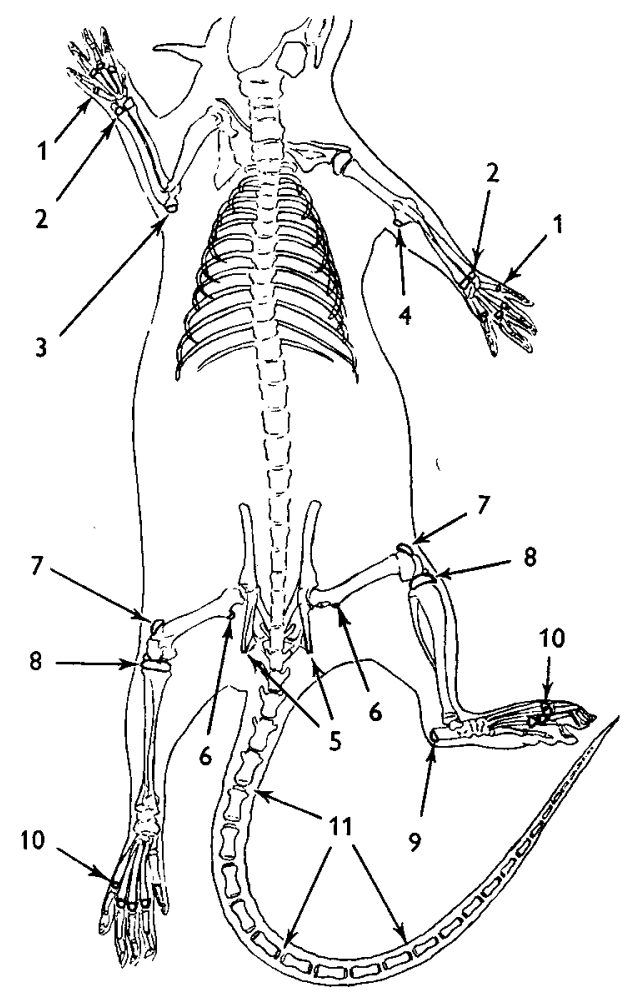

Fig. I. Tracing of a radiograph of a 40-day-old female rat to show some of the bony centres which may readily be studied when the animal is fastened in the position described. I, Epiphyses of metacarpals; 2, distal epiphyses of radius and ulna; 3 , olecranon process of ulna; 4 , medial epicondyle of humerus; 5 , epiphysis of ischial tuberosity; 6 , lesser trochanter; 7 , patella; 8 , proximal epiphysis of tibia; 9 , epiphysis of calcaneus; Io, epiphyses of metatarsals; I 1, caudal vertebrae.

numbered in sequence, the presence of indicator 4 means that indicators $\mathrm{I}-3$ have already appeared, and the sum total of indicators for any group of bones is a measure of the maturity of that part of the skeleton.

Choice of maturity indicators. Our radiographic studies were confined to the period between the 2oth and I I oth day of the rat's life. Therefore, of the many ossification centres shown in Pl. 4 and Fig. I we have concentrated on bones or bone groups that show unequivocal changes during this period. The resulting scale, although adequate for our purposes, is only one of many possible scales and should not be taken as an 
absolute standard for skeletal maturation. The assessment of skeletal maturity in the rat is somewhat complicated by the fact that the growth cartilage plates of many of its long bones remain unossified, so that the skeleton never becomes totally 'mature' in the sense that the human skeleton does. Nevertheless, the distribution of maturity points was so arranged that the maximum score an animal could achieve at the age of I Io days was roo. This method permits each of the scores to be considered as a percentage, a concept with some theoretical advantages for man (Acheson, 1954, I957). The details of the indicators recognized, and the points awarded to them, are shown in Table $\mathrm{I}$.

Table I. A scheme for assessing the skeletal maturity of rats up to the age of I 10 days by the Oxford method

\begin{tabular}{|c|c|c|}
\hline $\begin{array}{l}\text { Anatomical } \\
\text { region }\end{array}$ & Bone & Skeletal-maturity indicator \\
\hline \multirow[t]{2}{*}{ Fore-limb } & Metacarpals & $\begin{array}{l}\text { Ossification visible in all four } \\
\text { epiphyses } \\
\text { Osseous invasion of all four } \\
\text { growth cartilage plates }\end{array}$ \\
\hline & $\begin{array}{l}\text { Medial epicondyle } \\
\text { of humerus }\end{array}$ & $\begin{array}{l}\text { Ossification visible in epiphysis } \\
\text { Osseous invasion of growth } \\
\text { cartilage plate }\end{array}$ \\
\hline Trunk & Ischium & $\begin{array}{l}\text { Ossification in flake epiphysis of } \\
\text { tuberosity }\end{array}$ \\
\hline \multirow[t]{7}{*}{ Hind-limb } & Lesser trochanter & $\begin{array}{l}\text { Ossification visible in epiphysis } \\
\text { Osseous invasion of growth } \\
\text { cartilage plate }\end{array}$ \\
\hline & Patella & Ossification visible \\
\hline & $\begin{array}{l}\text { Proximal end of } \\
\text { tibia }\end{array}$ & $\begin{array}{l}\text { Ossification visible in epiphysis } \\
\text { Epiphysis as wide as diaphysis }\end{array}$ \\
\hline & Calcaneus & $\begin{array}{l}\text { Ossification visible in epiphysis } \\
\text { Osseous invasion of growth } \\
\text { cartilage plate }\end{array}$ \\
\hline & Metatarsals & $\begin{array}{l}\text { Ossification visible in all four } \\
\text { epiphyses }\end{array}$ \\
\hline & & $\begin{array}{l}\text { Acquisition of a stellate appear- } \\
\text { ance by all four epiphyses }\end{array}$ \\
\hline & & $\begin{array}{l}\text { Osseous invasion of all four } \\
\text { growth cartilage plates }\end{array}$ \\
\hline Tail & & $\begin{array}{l}\text { Ossification visible in both epi- } \\
\text { physes of a caudal vertebra (to } \\
\text { a maximum of } 25 \text { vertebrae) }\end{array}$ \\
\hline
\end{tabular}

$\begin{array}{ccc}\text { Points } & \text { Maximum } & \text { possible } \\ \text { score for } & \text { score per bone } & \frac{0}{\tilde{N}} \\ \text { each } & \text { och }\end{array}$

Total possible score
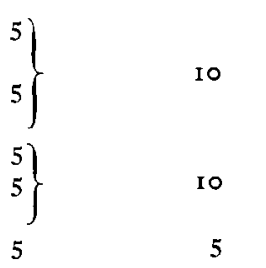

$5\} \quad 10$

5

5 5 I0

$\left.\begin{array}{l}5 \\ 5\end{array}\right\} \quad 10$

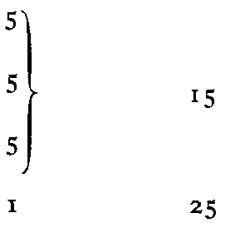

100

\section{RESULTS}

Total length. The mean total lengths for twenty-three animals (ten male and thirteen female) are shown by age and sex in Table 2.

Tail length. The mean tail length is presented by age and sex in Table 3 (the thickness of the end-board $(0.6 \mathrm{~cm})$ has been included).

Weight. For completeness of presentation the mean weights are given by age and sex in Table 4. 
Table 2. Total length $(\mathrm{cm})$ of ten male and thirteen female rats measured repeatedly

\begin{tabular}{|c|c|c|c|c|}
\hline \multirow{2}{*}{$\begin{array}{c}\text { Age } \\
\text { (days) }\end{array}$} & \multicolumn{2}{|c|}{ Male } & \multicolumn{2}{|c|}{ Female } \\
\hline & Mean & S.D. & Mean & S.D. \\
\hline I6 & 16.7 & 0.65 & $16 \cdot 2$ & 0.65 \\
\hline 17 & $17 \cdot 3$ & 0.75 & $16 \cdot 8$ & 0.55 \\
\hline 18 & $17 \cdot 7$ & $1 \cdot 00$ & $17 \cdot 2$ & 0.61 \\
\hline I9 & I $8 \cdot 0$ & 0.85 & $17 \cdot 6$ & 0.76 \\
\hline 20 & I $8 \cdot 5$ & 0.87 & I $8 \cdot I$ & 0.71 \\
\hline 21 & 19.0 & 0.91 & $18 \cdot 6$ & 0.65 \\
\hline 22 & $19 \cdot 2$ & $0.8 \mathrm{t}$ & $18 \cdot 8$ & 0.65 \\
\hline 23 & 19.9 & 0.96 & $19^{\circ} 0$ & 0.79 \\
\hline 24 & 20.5 & $1 \cdot 00$ & $19^{\cdot 6}$ & $0.7^{8}$ \\
\hline 25 & $2 I \cdot 0$ & 0.92 & $20 \cdot I$ & 0.57 \\
\hline 26 & $2 I \cdot 2$ & 1.05 & 20.4 & 0.71 \\
\hline 27 & $2 I \cdot 9$ & $I \cdot I 8$ & $20 \cdot 8$ & 0.61 \\
\hline 28 & $22 \cdot 2$ & $1 \cdot 27$ & $21 \cdot 5$ & 0.98 \\
\hline 29 & $22 \cdot 9$ & $1 \cdot 23$ & $22 \cdot 1$ & 0.96 \\
\hline 30 & $23 \cdot 4$ & $1 \cdot 03$ & $2.2 \cdot 4$ & 0.84 \\
\hline $3^{I}$ & $24^{\circ} 0$ & $I \cdot 16$ & $22 \cdot 7$ & 0.75 \\
\hline 32 & $24 \cdot 6$ & I. 34 & $23 \cdot 4$ & $I \cdot 07$ \\
\hline 33 & $25^{.2}$ & $I \cdot I 9$ & 23.7 & 0.94 \\
\hline 34 & 25.7 & 1.45 & $24 \cdot 2$ & $0.8 \mathrm{I}$ \\
\hline 35 & 26.0 & I. 35 & $24 \cdot 6$ & $I \cdot I 9$ \\
\hline 36 & $26 \cdot 4$ & $I \cdot 63$ & $25 \cdot 1$ & $1 \cdot 27$ \\
\hline 37 & $27 \cdot 0$ & $I \cdot 32$ & $25^{\circ} 8$ & $I \cdot 25$ \\
\hline $3^{8}$ & $27 \cdot 6$ & $I \cdot 32$ & $26 \cdot 2$ & $1 \cdot 22$ \\
\hline 39 & $28 \cdot 3$ & $I \cdot 5 I$ & 27.0 & $I \cdot I 9$ \\
\hline 40 & $29^{\circ} 9$ & I. 39 & $27 \cdot 9$ & $I \cdot 00$ \\
\hline 50 & $34 \cdot 3$ & $1 \cdot 50$ & $32 \cdot 8$ & $I \cdot 26$ \\
\hline 60 & $37 \cdot 4$ & $I \cdot 35$ & 34.9 & 0.84 \\
\hline 70 & $39 \cdot 6$ & $1 \cdot 19$ & $36 \cdot 4$ & 0.75 \\
\hline 90 & $4 I \cdot 5$ & $1 \cdot 30$ & $37 \cdot 8$ & 0.80 \\
\hline 110 & $43 \cdot 6$ & I. 59 & $38 \cdot 8$ & $I \cdot I 3$ \\
\hline
\end{tabular}

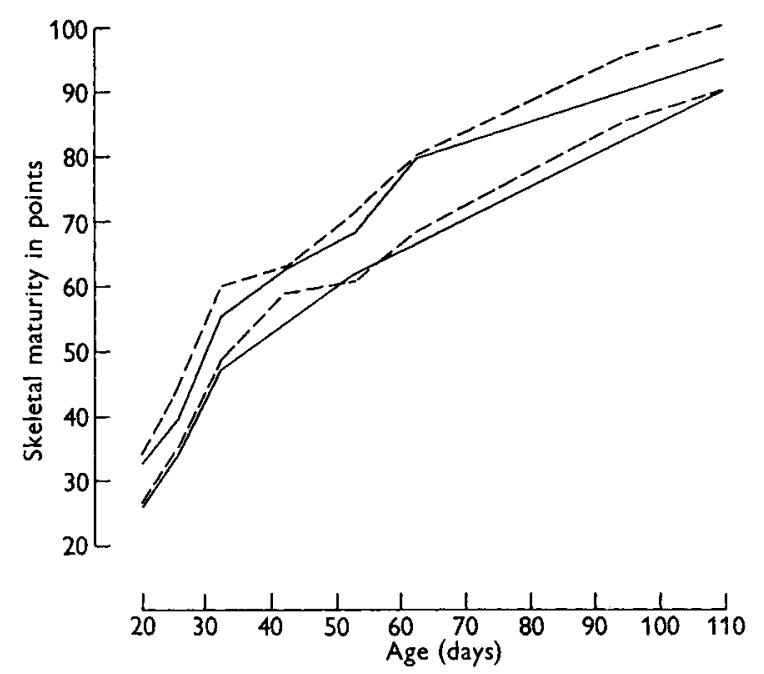

Fig. 2. Observed range of skeletal-maturity scores of rats by age and sex. ——, male; ,---- female. 
Skeletal maturity. Serial radiograms of ten healthy males and thirteen healthy females, taken at approximately Io-day intervals, were studied through the age period under investigation, and the maturity scores calculated for all selected bones on each $\mathrm{X}$-ray film were totalled. The mean scores in points, together with the observed ranges, are presented for each sex in Table 5 and Fig. 2. It did not always prove possible to radiograph all the rats on the same day, and the skeletal maturity of most of the animals at the ages shown in Table 5 was estimated by linear interpolation. The maxima and minima in Fig. 2 are, however, the extremes as they were observed.

Increments in total length, tail length, and weight. Mean increments, together with standard deviations, in total length, tail length and weight are shown in Table 6 . It will be seen that there is no evidence of a pre-adolescent growth spurt in either sex; Tanner (I955) could find little to suggest that such a spurt exists in the rat when he analysed published data giving details of weight increments.

Table 3. Tail length $(\mathrm{cm})$ of ten male and thirteen female rats measured repeatedly

\begin{tabular}{|c|c|c|c|c|}
\hline \multirow{2}{*}{$\begin{array}{c}\text { Age } \\
\text { (days) }\end{array}$} & \multicolumn{2}{|c|}{ Male } & \multicolumn{2}{|c|}{ Female } \\
\hline & Mean & S.D. & Mean & S.D. \\
\hline I6 & $7 \cdot 7$ & 0.23 & $7 \cdot 5$ & 0.24 \\
\hline I7 & $8 \cdot I$ & 0.25 & $7 \cdot 9$ & 0.24 \\
\hline 18 & $8 \cdot 5$ & 0.24 & $8 \cdot 3$ & 0.26 \\
\hline 19 & 8.9 & 0.22 & $8 \cdot 5$ & 0.28 \\
\hline 20 & $9 \cdot 2$ & 0.23 & $9 \cdot 0$ & 0.29 \\
\hline $2 \mathrm{I}$ & $9 \cdot 5$ & 0.25 & $9 \cdot 3$ & 0.26 \\
\hline 22 & $9 \cdot 6$ & 0.25 & $9 \cdot 5$ & 0.28 \\
\hline 23 & $9 \cdot 9$ & 0.31 & $9 \cdot 9$ & 0.27 \\
\hline 24 & 10.2 & 0.23 & $10 \cdot 2$ & 0.30 \\
\hline 25 & 10.4 & 0.20 & 10.5 & 0.30 \\
\hline 26 & 10.6 & 0.24 & 10.7 & 0.32 \\
\hline 27 & 10.9 & 0.21 & 10.9 & 0.32 \\
\hline 28 & $I I \cdot I$ & 0.28 & $11 \cdot 4$ & 0.32 \\
\hline 29 & I 1.5 & 0.30 & I $1 \cdot 6$ & 0.32 \\
\hline 30 & II 6 & 0.33 & $11 \cdot 8$ & 0.32 \\
\hline $3 \mathrm{I}$ & $I I \cdot 9$ & 0.32 & $12 \cdot I$ & 0.29 \\
\hline 32 & $12 \cdot 2$ & 0.30 & $12 \cdot 2$ & 0.32 \\
\hline 33 & $12 \cdot 3$ & 0.31 & 12.5 & 0.32 \\
\hline 34 & I $2 \cdot 6$ & 0.30 & $12 \cdot 7$ & 0.27 \\
\hline 35 & $12 \cdot 9$ & 0.33 & 12.9 & 0.32 \\
\hline $3^{6}$ & 13.4 & 0.35 & $13 \cdot 2$ & 0.27 \\
\hline 37 & 13.5 & 0.32 & 13.5 & 0.29 \\
\hline $3^{8}$ & 13.9 & 0.28 & I 3.8 & 0.25 \\
\hline 39 & 14.2 & 0.34 & 14.0 & 0.27 \\
\hline 40 & $14 \cdot 5$ & 0.24 & 14.4 & 0.25 \\
\hline 50 & 15.4 & 0.26 & $16 \cdot I$ & 0.25 \\
\hline 60 & $17 \cdot 2$ & 0.34 & $17 \cdot 2$ & 0.22 \\
\hline 70 & $19^{\circ} 6$ & 0.26 & I $8 \cdot 3$ & 0.19 \\
\hline 90 & $20 \cdot 2$ & 0.23 & $19 \cdot 3$ & 0.25 \\
\hline I10 & $2 I \cdot 2$ & 0.26 & $19 \cdot 8$ & 0.20 \\
\hline
\end{tabular}


Table 4. Weight (to nearest $g$ ) of ten male and thirteen female rats measured repeatedly

\begin{tabular}{|c|c|c|c|c|}
\hline \multirow{2}{*}{$\begin{array}{c}\text { Age } \\
\text { (days) }\end{array}$} & \multicolumn{2}{|c|}{ Male } & \multicolumn{2}{|c|}{ Female } \\
\hline & Mean & S.D. & Mean & S.D. \\
\hline 16 & 33 & $5 \cdot 6$ & 30 & 5.0 \\
\hline I7 & 34 & $5^{\cdot 6}$ & 32 & $4 \cdot 5$ \\
\hline I 8 & 37 & $6 \cdot 1$ & 33 & $5 \cdot 0$ \\
\hline I9 & 39 & $6 \cdot 7$ & 35 & $6 \cdot 2$ \\
\hline 20 & 42 & $5 \cdot 2$ & 36 & $6 \cdot 2$ \\
\hline $2 I$ & $4 \mathrm{I}$ & $7 \cdot 3$ & 35 & $6 \cdot 2$ \\
\hline 22 & $4^{6}$ & $7 \cdot 0$ & $3^{8}$ & $7 \cdot 5$ \\
\hline 23 & $5 \mathrm{I}$ & $8 \cdot 8$ & 43 & $8 \cdot I$ \\
\hline 24 & 55 & $11 \cdot 0$ & 47 & $8 \cdot 3$ \\
\hline 25 & $6 I$ & 10.2 & 52 & $8 \cdot 3$ \\
\hline 26 & 64 & $11 \cdot 6$ & 55 & $8 \cdot 3$ \\
\hline 27 & 70 & $11 \cdot 6$ & 60 & $9 \cdot 0$ \\
\hline 28 & 75 & 14.9 & 66 & 10.7 \\
\hline 29 & 80 & $15^{\cdot 2}$ & 70 & 10.1 \\
\hline 30 & 87 & 16.5 & 74 & II. 6 \\
\hline 31 & 90 & $15 \cdot 8$ & 79 & 13.0 \\
\hline 32 & 96 & $16 \cdot 3$ & $8 I$ & I $1 \cdot 9$ \\
\hline 33 & 100 & $18 \cdot 5$ & 85 & $12 \cdot 2$ \\
\hline 34 & 106 & $19^{\circ} \circ$ & 89 & $14 \cdot 8$ \\
\hline 35 & II 3 & $20 \cdot 5$ & 95 & $14 \cdot 5$ \\
\hline $3^{6}$ & 120 & $22 \cdot 5$ & 100 & $12 \cdot 7$ \\
\hline 37 & 126 & $23 \cdot 9$ & 104 & $14^{\circ} \mathrm{I}$ \\
\hline $3^{8}$ & I33 & 23.4 & 108 & 13.4 \\
\hline 39 & 142 & $24^{\circ} I$ & I I 4 & 13.6 \\
\hline 40 & I 49 & 23.0 & 122 & $12 \cdot 2$ \\
\hline 50 & 201 & $27 \cdot 2$ & I 5 I & $14: 7$ \\
\hline 60 & 245 & $24 \cdot 6$ & 168 & 10.6 \\
\hline 70 & 294 & $25^{\circ} 6$ & I 82 & 14.7 \\
\hline 90 & 331 & $30 \cdot 4$ & 204 & $13^{\circ} I$ \\
\hline I 10 & $35^{6}$ & $27 \cdot 0$ & 210 & $18 \cdot 4$ \\
\hline
\end{tabular}

Table 5. Estimated skeletal maturity status assessed in points by the Oxford method of ten male and thirteen female rats radiographed repeatedly

\begin{tabular}{|c|c|c|c|c|c|c|}
\hline \multirow{3}{*}{$\begin{array}{l}\text { Age } \\
\text { (days) }\end{array}$} & \multicolumn{3}{|c|}{ Male } & \multicolumn{3}{|c|}{ Female } \\
\hline & \multirow[b]{2}{*}{ Mean } & \multicolumn{2}{|c|}{ Range } & \multirow[b]{2}{*}{ Mean } & \multicolumn{2}{|c|}{ Range } \\
\hline & & Minimum & Maximum & & Minimum & Maximum \\
\hline 20 & $3 \mathbf{I}$ & 26 & 33 & 30 & 27 & 34 \\
\hline 30 & 46 & 43 & 50 & 49 & 43 & 56 \\
\hline 40 & 56 & 53 & 61 & 59 & 58 & 62 \\
\hline 50 & 62 & 59 & 66 & 63 & 60 & 68 \\
\hline 60 & 71 & 65 & 77 & 71 & 67 & 77 \\
\hline 70 & 77 & 70 & 82 & 77 & 72 & 83 \\
\hline 90 & 85 & 80 & 90 & 86 & $8_{3}$ & 93 \\
\hline 110 & 94 & 90 & 95 & 95 & 90 & 100 \\
\hline
\end{tabular}


Table 6. Daily increments in total length and tail length $(\mathrm{cm})$ and weight $(\mathrm{g})$ of ten male and thirteen female rats from ages 16 to 40 days

\begin{tabular}{|c|c|c|c|c|c|c|}
\hline \multirow{2}{*}{$\begin{array}{c}\text { Day of } \\
\text { life }\end{array}$} & \multicolumn{2}{|c|}{ Total length } & \multicolumn{2}{|c|}{ Tail length } & \multicolumn{2}{|c|}{ Weight } \\
\hline & Mean & S.D. & Mean & S.D. & Mean & S.D. \\
\hline \multicolumn{7}{|c|}{ Male rats } \\
\hline I $7^{\text {th }}$ & 0.6 & 0.29 & 0.5 & 0.14 & $\mathbf{I}$ & 0.9 \\
\hline I 8th & 0.4 & 0.27 & 0.4 & 0.14 & 3 & $I \cdot I$ \\
\hline Igth & 0.3 & 0.24 & 0.3 & 0.22 & 2 & $I \cdot I$ \\
\hline 2oth & 0.5 & 0.40 & $0 \cdot 3$ & 0.14 & 3 & $\mathrm{I} \cdot 7$ \\
\hline 2 Ist & 0.5 & 0.54 & $0 \cdot 3$ & 0.24 & $-I$ & $2 \cdot 3$ \\
\hline 22nd & 0.2 & $0.3^{\circ}$ & 0.1 & 0.17 & 5 & $I \cdot 7$ \\
\hline $23^{\mathrm{rd}}$ & 0.7 & 0.52 & 0.3 & 0.14 & 5 & 0.9 \\
\hline $24^{\text {th }}$ & 0.6 & 0.36 & 0.3 & 0.14 & 4 & $1 \cdot 7$ \\
\hline 25 th & 0.6 & $0 \cdot 18$ & 0.2 & 0.20 & 6 & $3 \cdot 9$ \\
\hline 26 th & 0.2 & 0.30 & 0.2 & 0.26 & 3 & $x \cdot 6$ \\
\hline 27 th & 0.6 & 0.34 & 0.3 & 0.17 & 6 & $2 \cdot 7$ \\
\hline 28th & 0.3 & 0.57 & 0.2 & 0.17 & 5 & $2 \cdot 7$ \\
\hline 29 th & 0.7 & 0.21 & 0.4 & 0.14 & 5 & $2 \cdot I$ \\
\hline 3oth & 0.5 & 0.39 & 0.1 & 0.20 & 7 & $2 \cdot 9$ \\
\hline 3 ist & 0.6 & 0.34 & 0.3 & 0.26 & 3 & $1 \cdot 6$ \\
\hline 32 nd & 0.6 & 0.40 & 0.3 & 0.10 & 6 & $2 \cdot 5$ \\
\hline $33 \mathrm{rd}$ & 0.6 & 0.20 & $0 \cdot 1$ & 0.28 & 4 & $I \cdot 7$ \\
\hline $34^{\text {th }}$ & 0.5 & 0.33 & 0.3 & 0.20 & 6 & 2.9 \\
\hline $35^{\text {th }}$ & 0.4 & 0.35 & 0.3 & 0.20 & 7 & $3 \cdot 2$ \\
\hline 36 th & 0.4 & 0.40 & 0.4 & 0.14 & 7 & $4 \cdot 3$ \\
\hline 37 th & 0.6 & 0.31 & 0.2 & 0.32 & 6 & $2 \cdot 6$ \\
\hline $3^{8 \text { th }}$ & 0.5 & 0.45 & 0.4 & 0.26 & 7 & $4 \cdot 0$ \\
\hline 39 th & 0.7 & 0.28 & 0.3 & 0.14 & 9 & $5 \cdot 4$ \\
\hline 4oth & $I \cdot 6$ & $0.4 I$ & 0.3 & 0.24 & 7 & $3 \cdot 3$ \\
\hline \multicolumn{7}{|c|}{ Female rats } \\
\hline I 7 th & 0.6 & 0.33 & 0.4 & 0.14 & 2 & $I \cdot 4$ \\
\hline I 8 th & 0.4 & 0.27 & 0.4 & 0.20 & $\mathbf{I}$ & 0.9 \\
\hline roth & 0.4 & 0.27 & 0.3 & 0.24 & 2 & $I \cdot 7$ \\
\hline 2oth & 0.5 & 0.26 & 0.4 & 0.10 & $\mathbf{I}$ & $I \cdot I$ \\
\hline 2 Ist & 0.5 & 0.36 & 0.3 & 0.20 & $-I$ & $3 \cdot 0$ \\
\hline 22nd & 0.2 & 0.51 & 0.2 & 0.22 & 3 & 0.9 \\
\hline $23 \mathrm{rd}$ & 0.6 & 0.23 & 0.4 & 0.10 & 5 & $I \cdot 6$ \\
\hline $24^{\text {th }}$ & 0.5 & 0.33 & 0.3 & 0.14 & 4 & 0.9 \\
\hline $25^{\text {th }}$ & 0.3 & 0.25 & $0 \cdot 3$ & 0.17 & 5 & $2 \cdot 9$ \\
\hline 26 th & 0.4 & 0.40 & $0 \cdot 2$ & 0.20 & 3 & $2 \cdot 5$ \\
\hline $27^{\text {th }}$ & 0.7 & 0.46 & 0.2 & 0.20 & 5 & $2 \cdot 6$ \\
\hline 28th & 0.4 & 0.40 & 0.4 & 0.20 & 6 & $I \cdot 5$ \\
\hline 29 th & $0 . \dot{6}$ & O.I 6 & 0.3 & 0.14 & 4 & 3.0 \\
\hline 3oth & 0.3 & 0.34 & 0.2 & 0.17 & 4 & $I \cdot 4$ \\
\hline 3 Ist & 0.3 & 0.25 & $0 \cdot 3$ & 0.22 & 5 & $3 \cdot 0$ \\
\hline 32nd & 0.7 & 0.25 & $O \cdot I$ & 0.17 & 2 & $I \cdot 4$ \\
\hline $33 \mathrm{rd}$ & 0.3 & 0.34 & 0.3 & 0.14 & 4 & $2 \cdot 1$ \\
\hline $34^{\text {th }}$ & 0.5 & 0.34 & 0.2 & 0.17 & 4 & $2 \cdot I$ \\
\hline $35^{\text {th }}$ & 0.4 & 0.34 & 0.2 & 0.10 & 6 & $3 \cdot 2$ \\
\hline 36 th & 0.5 & 0.35 & 0.3 & 0.14 & 5 & $4 \cdot 2$ \\
\hline $37^{\text {th }}$ & 0.7 & 0.34 & 0.3 & 0.10 & 4 & $2 \cdot 6$ \\
\hline 38 th & 0.4 & 0.35 & 0.3 & 0.14 & 4 & 3.0 \\
\hline 39 th & 0.8 & 0.47 & 0.2 & 0.22 & 6 & 4.0 \\
\hline 4oth & 0.9 & 0.31 & 0.4 & 0.24 & 8 & 3.4 \\
\hline
\end{tabular}




\section{DISCUSSION}

Several broad similarities in the developmental patterns of rat and human skeletons are worth noting. Various workers (Strong, 1925; Scow, Simpson, Asling, Li \& Evans, 1949; Ray et al. 1950) have contended that the 'lead' in rate of skeletal maturation shown by the human female over the male could not be detected in the rat. Spark \& Dawson (1928), however, suggested tentatively that the female rat matures more quickly, and our findings support that conclusion. Not only do the female skeletal-maturity scores shown in Table 5 and Fig. 2 tend to be higher than the male, but also growth of body length in the female slows by the 7oth or 8oth day, whereas it continues for a considerably longer period in the male. At all stages studied in this work, the male rat, like the male human being, was longer and heavier than the female.

A further similarity of importance between the rat and man is that both are skeletally immature at birth, so that much of the transformation of the cartilage into bone occurs when the animal is no longer protected by the constant environment of the uterus; in this respect the rat is unlike some other laboratory animals, such as the guinea-pig. Thus the response of skeletal development to environmental stress may be readily studied in the rat. It is many years now since it was shown, notably by Evans's group (Scow \& Marx, I945; Becks, Simpson, Scow, Asling \& Evans, 1948; Becks, Scow, Simpson, Asling, Li \& Evans, 1950), that the consideration of skeletal maturation and growth in bone length added greatly to the value of studies of the physical development of the rat, yet most workers engaged in nutritional, endocrinological, pharmacological and biochemical research are still content to use weight as the sole day-to-day index of growth. We strongly urge them to include in such studies the daily measurements of total length, together with periodic radiography. In this way further light could be cast on the nature of the delicate balance that exists between chondroplasia and osteogenesis both in man (Acheson \& Hewitt, 1954; Hewitt, Westropp \& Acheson, I955) and in the rat (Acheson \& Macintyre, 1958 $a$; Acheson, 1959). Such studies would almost certainly improve the understanding of some of the minor aberrations in physical development that occur so frequently in the human child.

\section{SUMMARY}

I. A simple method is described for the daily measurement of total length and tail length in the conscious rat. Albino rats (ten males and thirteen females) were measured periodically between the I6th and I roth day of life; mean values with standard deviations are given by age and sex for total length, tail length and daily increments for both from the $I 7$ th to the 40 th day.

2. Mean weights and increments in weight (with standard deviations) of the same rats, recorded on the same days, are shown.

3. A standard position is described in which the rat may be radiographed in order to show the maximum number of ossifying centres on a single X-ray film. Details are given of anaesthetic and radiographic procedures.

4. The Oxford method of assessing skeletal maturity was applied to the rat, and tentative standards are shown, suitable for use between the 20th and I I oth days of life. 
5. It is urged that free use of total length and assessment of skeletal maturity would add much to the value of nutritional, endocrinological and other experiments in which growth is studied. To date, weight increment has too frequently been the only measure of growth.

We are grateful to the late Dr Normand L. Hoerr, Director of the Department of Anatomy, Western Reserve University, when the work was done, for his interest and encouragement during the experiments, and to Professor W. J. E. Jessop, Moyne Institute, Trinity College, Dublin, for criticizing the text. This investigation was supported in part by grants from the (U.S.) National Science Foundation; the Committee for Research in Problems of Sex, (U.S.) National Academy of SciencesNational Research Council; the Medical Research Council of Ireland.

\section{REFERENCES}

Acheson, R. M. (1954). F. Anat., Lond., 88, 498.

Acheson, R. M. (1956). Anat. Rec. 124, 250.

Acheson, R. M. (1957). Clin. Orthop. 10, 19.

Acheson, R. M. (1959). F. Anat., Lond., 93, 123.

Acheson, R. M. \& Hewitt, D. (1954), Brit. F. prev. soc. Med. 8, 59.

Acheson, R. M. \& Macintyre, M. N. (1958a). Brit. F. exp. Path. 39, 37.

Acheson, R. M. \& Macintyre, N. M. (1958b). Irish. F. med. Sci. Ser. 6, p. 37.

Becks, H., Scow, R. O., Simpson, M. E., Asling, C. W., Li, C. H. \& Evans, H. M. (1950). Anat. Rec. 107, 299.

Becks, H., Simpson, M. E., Scow, R. O., Asling, C. W. \& Evans, H. M. (1948). Anat. Rec. 100, 56r. Hewitt, D., Westropp, C. K. \& Acheson, R. M. (1955). Brit. F. prev. soc. Med. 9, 179.

Ingalls, T. H. (1941). Endocrinology, 29, 710.

Ray, R. D., Simpson, M. E., Li, C. H., Asling, C. W. \& Evans, H. M. (1950). Amer. F. Anat. 86, 479.

Scow, R. O. \& Marx, W. (1945). Anat. Rec. 91, 227.

Scow, R. O., Simpson, M. E., Asling, C. W., Li, C. H. \& Evans, H. M. (I949). Anat. Rec. I04, 445.

Simpson, M. E., Asling, C. W. \& Evans, H. M. (1950). Yale F. Biol. Med. 23, I.

Spark, C. \& Dawson, A. B. (1928). Amer. F. Anat. 4r, 4 I r.

Strong, R. M. (1925). Amer. F. Anat. 36, 313 .

Tanner, J. M. (1955). Growth at Adolescence, ist ed. Oxford: Blackwell.

\section{EXPLANATION OF PLATES}

a. The Western Reserve measuring board.

Plate I

b. Measurement of the total length of the conscious rat. Stage I. The animal is grasped by the scruff of the neck with the left hand, and the root of the tail with the right.

Plate 2

a. Measurement of the total length of the conscious rat. Stage 2. The animal is placed on the board with its nose against the end-piece. Note the thenar eminence of the left hand along the spine to prevent back-humping.

b. Stage 3. With the right hand acting as a fixed point, the left hand is released; the tail is then straightened, and the total-length measurement recorded.

\section{Plate 3}

a. The technique used for the measurement of the tail length.

b. The position in which the animals were radiographed, so as to show the maximum number of centres undergoing ossification on a single X-ray film. Note the limbs secured in position with adhesive Cellophane tape. (For further details see text.)

\section{Plate 4}

A radiograph taken in the manner described. The animal shown is a healthy female aged 40 days. 
ELEANOR OLDHAM. Skeletal Development IN THE RAT
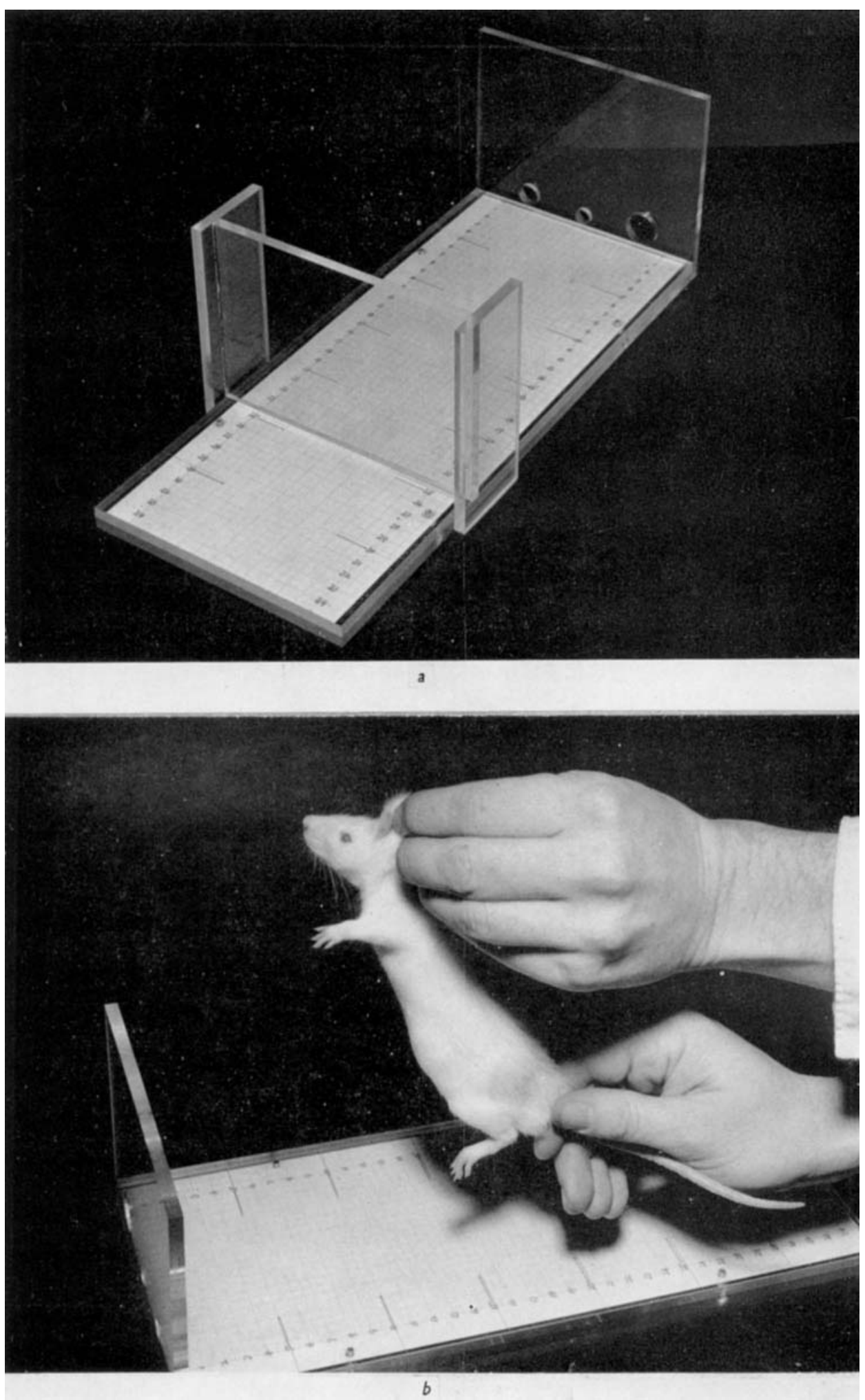

British Fournal of Nutrition, Vol. I3, No. 3 
ROY M. ACHESON, M. NEIL MACINTYRE AND

Plate 2

ELEANOR OLDHAM. Skeletal Development in the Rat
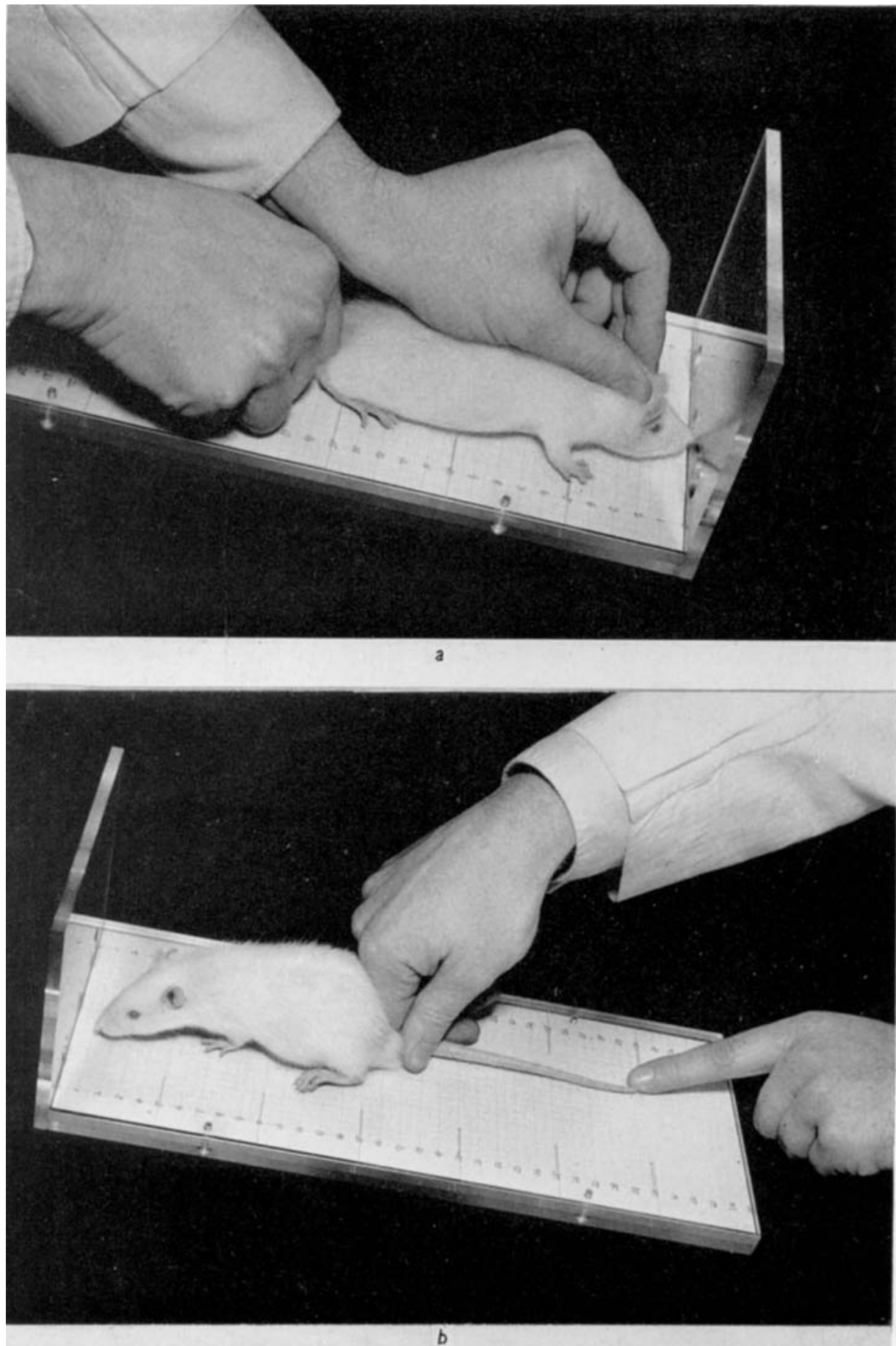

British Fournal of Nutrition, Vol. I3, No. 3 
ROY M. ACHESON, M. NEIL MACINTYRE AND

Plate 3

ELEANOR OLDHAM. SkELETAL DEVELOPMENT IN THE RAT
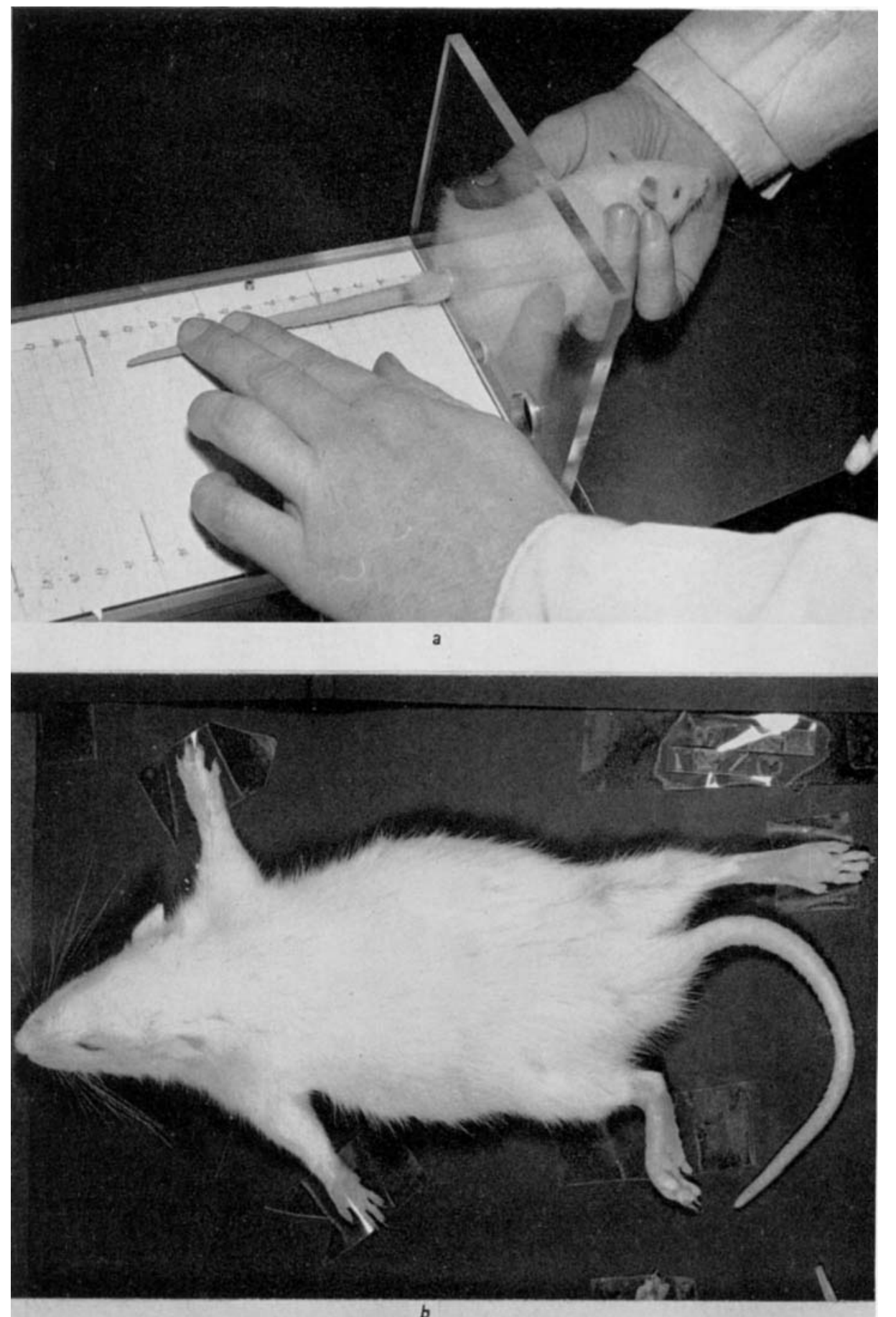

British Gournal of Nutrition, Vol. 13, No. 3 
ROY M. ACHESON, M. NEIL MACINTYRE AND

Plate 4

ELEANOR OLDHAM. Skeletal DEVELOPMENT in THE RAT

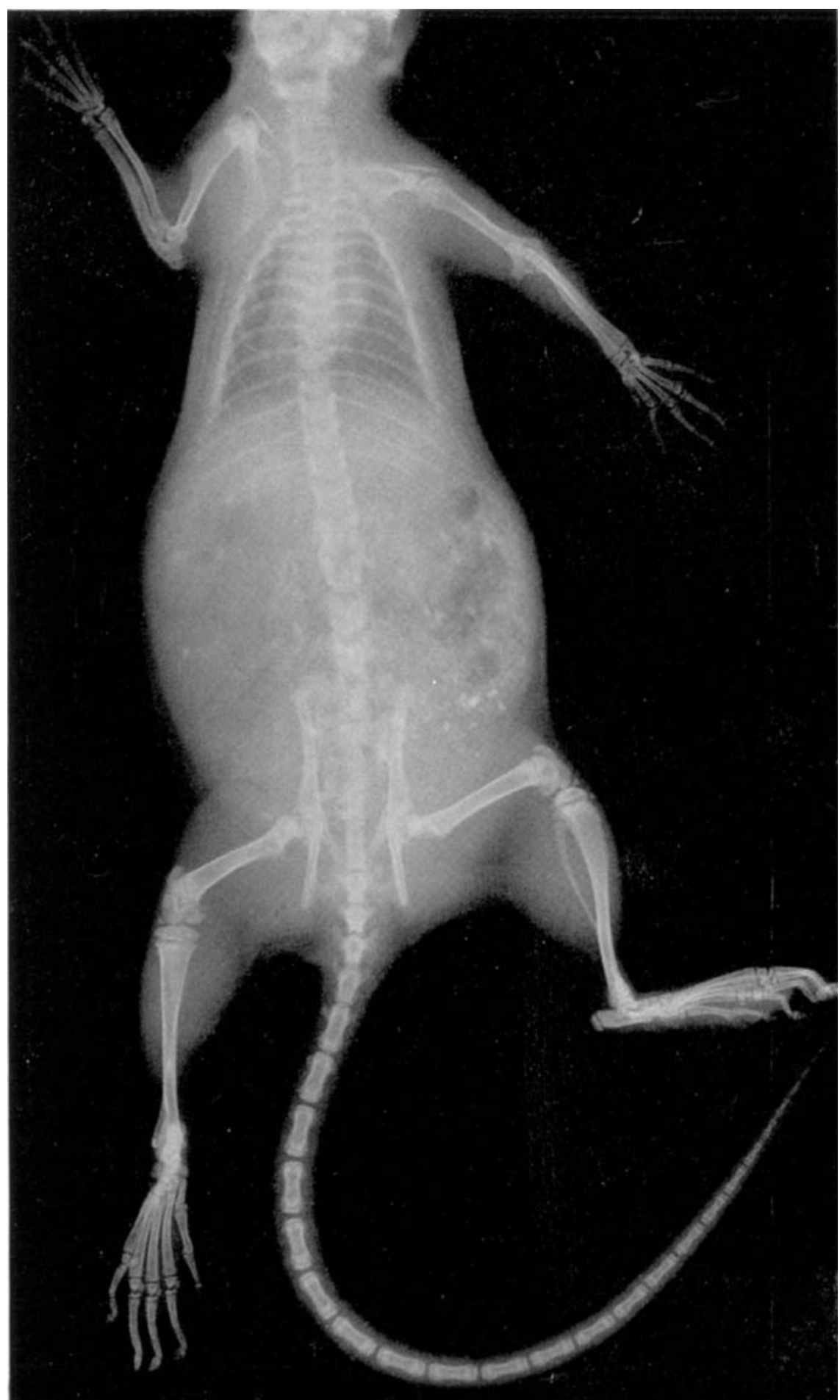

British Fournal of Nutrition, Vol. 13, No. 3 